\title{
(1) Challenging Imperial Feminism
}

\section{Valerie Amos and Pratibha Parmar}

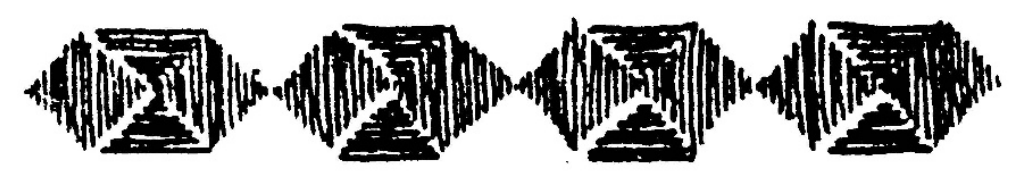

Our task here is to begin to identify the ways in which a particular tradition, white Eurocentric and Western, has sought to establish itself as the only legitimate feminism in current political practice. We seek to address ourselves in very broad terms, to the theoretical and consequently political limitations of Euro-American feminism and the ways such analyses inform and distort white women's political practice. In challenging such feminist writings we not only look at the ways in which analyses of racism have been significantly lacking from that work but equally importantly we look at the ways in which we as Black women have been made 'visible' in such writings and the terms in which our experiences have been explained.

The growth of the Black feminist movement in Britain in the last decade has forced the question of the centrality of Black women's oppression and exploitation onto the political and theoretical agendas. The political energy of Black women who have organized at the grassroots within our communities against the myriad of issues engendered by the racism of the British state has inspired and pointed to the urgent need to challenge many of the theoretical conceptualizations and descriptions of Black and Third World women existing within white feminist literature.

Bell Hook's argument (1982) that racism in the women's movement in the USA has acted to exclude the participation of Black women is equally applicable to the British situation:

From a Black female perspective, if white women are denying the existence of Black women, writing 'feminist' scholarship as if Black women are not part of the collective group of American women, or discriminating against Black women, then it matters less that North America was colonised by white patriarchal men who institutionalised a radically imperialistic social order, than that white women who purport to be feminists support and actively perpetuate anti-Black racism.

It is our aim in this article to critically examine some of the key theoretical concepts in white feminist literature, and discuss their relevance or otherwise for a discussion and development of Black feminist theory. 
It would be naive of us to suggest in any way that the white women's movement is a monolithic structure or organization, indeed we recognise that it is a variety of groups with a diversity of interests and perspectives.

However, our concern here is to show that white, mainstream feminist theory, be it from the socialist feminist or radical feminist perspective, does not speak to the experiences of Black women and where it attempts to do so it is often from a racist perspective and reasoning.

In terms of practice, while there are a broad range of issues and demands that white feminists are engaged in, we believe there is a particular kind of implicit concensus amongst these women about the issues which are thought to be important to organize around. The limitations of the movement are expressed in the issues which are identified as priorities: they are issues which in the main have contributed to an improvement in the material situation of a small number of white middle-class women often at the expense of their Black and working class 'sisters', e.g. short term gains such as equal opportunities and job sharing. The power of sisterhood stops at the point at which hard political decisions need to be made and political priorities decided. In the same way that the Labour movement has lamented the supposed lack of involvement of Black people in their struggles so white women have condemned Black women for not engaging in the struggles they have identified as important - the colonial heritage marches on.

This unconscious consensus has been successful in excluding large numbers of Black women from participating in any meaningful way. A further element contributing to Black women's exclusion is due to the fact that very often women's oppression is seen in a straightforward and non-contradictory way, where women organizing as women is seen as positive, regardless of the context. An example of such reasoning taken to its extreme is when some white feminists have applauded Maggie Thatcher as Prime Minister as a positive female image. Such uncritical acceptance of the virtues of strong female images serves only to further alienate Black women whose experience at the hands of the British state demands a more responsible political response.

Our starting point then is the oppressive nature of the women's movement in Britain both in terms of its practice and the theories which have sought to explain the nature of women's oppression and legitimize the political practices which have developed out of those analyses. In describing the women's movement as oppressive we refer to the experiences of Black and working class women of the movement and the inability of feminist theory to speak to their experience in any meaningful way.'

In arguing that most contemporary feminist theory does not begin to adequately account for the experience of Black women we also have to acknowledge that it is not a simple question of their absence, consequently the task is not one of rendering their visibility.

On the contrary we will have to argue that the process of accounting for their historical and contemporary position does, in itself, challenge the use of some of the central categories and assumptions of recent mainstream feminist thought (Carby, 1982). This work has already begun; Black women are not only making history but rewriting it.

The publication in recent years of a number of books by Black feminists in the US marks the beginning of a systematic documentation of Black women's individual and collective histories. Dominant among these are the rediscovery of ourselves; our place

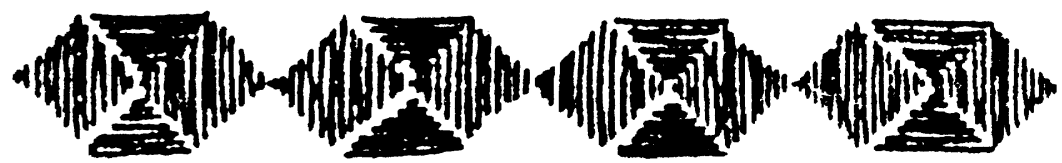


in the Black movement; the boundaries of our sisterhood with white feminists (Lewis and Parmar, 1983).

These are important areas for us Black women, for our experience is the shared experience of Black people but it is also the shared experience of women within different class contexts. Our political responses have been and will continue to be shaped by that duality, the range of political options available to us will depend on the social context in which we experience that dualism. To date, the majority of work available by Black women addresses itself to the situation in the USA or to the situation in the Third World countries from which our ancestors are drawn. Although comparisons can be made between Britain and the USA and although it is important to draw on the histories of the communities and countries of the Third World which have contributed to our world view, it is important that Black women in Britain locate their experiences within the context of what is happening to Black people here.

There is little recognition in the women's movement of the ways in which the gains made by white women have been and still are at the expense of Black women. Historically white women's sexuality has been constructed in oppositional terms to that of Black women (Davis 1982, Ware 1983). and it is to this history that white women refer as their starting point, it is with this history that they seek to come to terms but in an uncritical way - the engagement with it is essentially selective. The 'herstory' which white women use to trace the roots of women's oppression or to justify some form of political practice is an imperial history rooted in the prejudices of colonial and neo-colonial periods, a 'herstory' which suffers the same form of historical amnesia of white male historians, by ignoring the fundamental ways in which white women have benefitted from the oppression of Black people. What forms of contemporary feminist and socialist theories share is an inability to adequately deal with the contradictions inherent in gender and class relations within the context of a racist society. 'Race and sex are social realities which at particular historical moments structure class relations in as much as class relations structure them' (Lewis and Parmar, 1983).

Thus the perception white middle-class feminists have of what they need liberating from has little or no relevance to the day to day experience of the majority of Black women in Britain and the ways in which they determine the political choices which have to be made. Nowhere is this more apparent than in the oppositional terms in which women's liberation and Black people's liberation has been and still is posed. In her analysis of the women's suffrage movement in the USA and the Abolition of Slavery Campaigns, Angela Davis pointed to the opportunistic and racist arguments of some white women who made simplistic comparisons between the position of Black men and white women in 19th century America (Davis, 1982). One such woman Elizabeth Cady Stanton wrote in 1865 :

The representation of women of the nation have done their uttermost for the last 30 years to secure freedom for the negroes and as long as he was the lowest in the scale of being we were willing to press his claims but now, as the celestial gate to civil rights is slowly moving on its hinges, it becomes a serious question whether we had better stand aside and see 'sambo' walk into the kingdom first (Davis, 1982).

This line of reasoning was not only limited to the USA; the movement for female

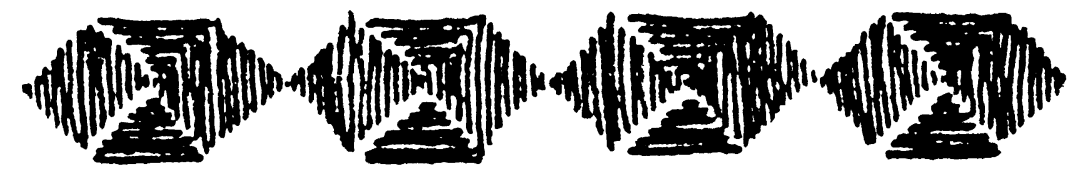


emancipation in Britain was closely linked to theories of racial superiority and Empire.

It would appear that although feminists and indeed Marxists invoke the spectre of history/herstory at will in an attempt to locate the articulation of class and gender oppression, at the point at which that very history is called into question and challenges the bases of their analyses there is a curious kind of amnesia. The past is invoked at will, but differentially, to make sense of the range of political options open to socialists and feminists. ${ }^{2}$

Few white feminists in Britain and elsewhere have elevated the question of racism to the level of primacy, within their practical political activities or in their intellectual work. The women's movement has unquestioningly been premised on a celebration of 'sisterhood' with its implicit assumption that women qua women have a necessary basis for unity and solidarity; a sentiment reflected in academic feminist writings which is inevitably influenced by the women's movement and incorporates some of its assumptions.

While one tendency has been for Black women to have either remained invisible within feminist scholarship or to have been treated purely as women without any significance attached to our colour and race, another tendency has been the idealization and culturalism of anthropological works. Often we have appeared in cross cultural studies which under the guise of feminist and progressive anthropology, renders us as 'subjects' for 'interesting' and 'exotic' comparison. For instance, the book Women United Women Divided looked at women's solidarity in cross cultural perspectives and 'discovered' that solidarity was no unitary concept. The authors defined feminist consciousness and then proceeded to judge other cultural situations to see if they are feminist or not. While acknowledging that there are problems about uncritically accepting women as a universal category, this is purely on the basis of 'differential relations in class and status hierarchies as well as factors such as age and kinship affiliation.' There is no apology for, nay awareness even, of the contradictions of white feminists as anthropologists studying village women in India, Africa, China for evidence of feminist consciousness and female solidarity. Furthermore, one wonders why they find it easier to study middle-class women in India and their organizations to prove that 'these women organise to protect class privilege in activities that complement their husbands' objective positions in the class hierarchy' than to study or examine the class position of the majority of the white women in the women's organizations in Western Europe; to examine how these women have different interests and power according to their class, age, race and sexuality and organize accordingly to protect their interests. By adopting the research methods and frameworks of white male academics much academic feminist writing fails to challenge their assumptions, repeats their racial chauvinism and is consequently of less use to us.

One such assumption is that pre-capitalist economies equal backwardness in both a cultural and ideological sense and in fact are responsible for the continued oppression of women in these societies. It is further implied that it is only when Third World women enter into capitalist relations will they have any hope of liberation:

There can be little doubt that on balance the position of women in imperialist, i.e. advanced capitalist societies is, for all its implications more advanced than in the less developed capitalist and non capitalist societies. In this sense the changes brought by imperialism to Third World societies may, in some circumstances have been historically progressive(Molyneux, 1981).

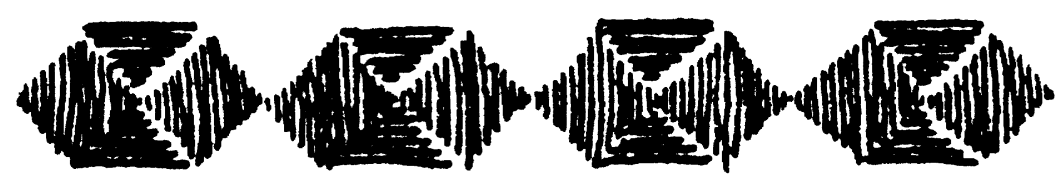


The above analysis falsely assumes that imperialism necessarily brings capitalist relations and is parallel to the resurgence of development theories in neo-marxist literature that argue that imperialism is progressive for 'underdeveloped' nations (Warren, 1980; for critique see Sivanandan, 1982).

Furthermore, when Black and Third World women are being told that imperialism is good for us, it should be of no great surprise to anyone when we reject a feminism which uses Western social and economic systems to judge and make pronouncements about how Third World women can become emancipated. Feminist theories which examine our cultural practices as 'feudal residues' or label us 'traditional', also portray us as politically immature women who need to be versed and schooled in the ethos of Western feminism. They need to be continually challenged, exposed for their racism and denied any legitimacy as authentic feminists.

\section{Strength in Differences}

The failure of the academic feminists to recognise difference as a crucial strength is a failure to reach beyond the first patriarchal lesson. Divide and conquer in our world must become define and empower (Lorde, 1981).

Many white feminists' failure to acknowledge the differences between themselves and Black and Third World women has contributed to the predominantly Eurocentric and ethnocentric theories of women's oppression. Recently, some white feminist academics have attempted to deal with the question of differences but again this has raised many problems and often perpetuated white feminist supremacy. In Common Differences, Jill Lewis, who describes herself as a white socialist feminist and Gloria Joseph, a Black woman, attempt to create a dialogue but rather than use this opportunity to find constructive and creative ways of strengthening our unity through our differences as Black and white feminists, Jill Lewis reveals her patronizing and condescending 'understanding' of Black women. She sets out to teach the $\mathrm{A}$ to $\mathrm{Z}$ of feminism to Black women, whom she portrays as women controlled, manipulated and brainwashed into ridiculing and dismissing the women's liberation movement by sexist Black men and the white male media (Joseph and Lewis, 1981). There is a blatant disregard for the fact that it is the autonomous activities of Black women which have forced the white women's movement away from a celebration of universality and sameness, to be concerned with the implications of differences among women's experiences and understanding the political factors at work in those differences.

Again she doesn't acknowledge the struggles of Black sisters both within the women's liberation movement and outside of it, who have fought for our presence and our issues to be on the agendas in a range of political organizations and who have struggled to raise racism as a central issue within the women's movement. Instead she distorts history and gives credit where it is not due:

From its beginnings, the movement turned to Chicano, Puerto Rican and Black women to give account (sic) of their particular experiences of oppression, though the movement as a whole has had difficulty digesting the implications of these and shifting its central perspectives away from the perspectives of its white majority (Joseph and Lewis, 1981).

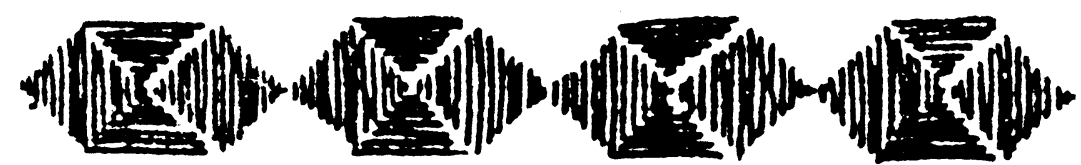


Historically, it was not the movement who turned to these women but Black women themselves who instigated the debates on our differences. For instance in America, many Black women were involved in the women's movement from its beginnings, and they struggled to bring home the following to their Black sisters who were pessimistic about the viability of joint political work with white feminists:

The real political and economic advances acquired by women of colour involved in the women's movement more than made up for the very real problems and personal contradictions evident among certain petty bourgeois white women's 'leaders' (Marabelle, 1983).

Black women were also raising the issue of feminism and feminist demands within the Black movement and such questions were continually raised in the civil rights movement well before Black women were engaging in debate within the predominantly white women's movement in the 1960s. In not acknowledging the involvement of Black women in the women's movement in its early days, Jill Lewis not only distorts history and renders Black women activists invisible, she also ends up by appropriating feminism for white women. Throughout her writings there is an underlying idea that somehow feminism, and feminist demands which are of any relevance and validity, have been developed by white women.

The feminist authors we have criticized are not the only ones guilty of using Eurocentric models, frameworks and definitions which leave no room for validating the struggles and concerns of Black and Third World women, there are many others. Because they are not acquainted with traditions outside of their own cultures and histories, the ideological and the theoretical legacies that they write from inevitably deny as valid any modes of struggle and organization which have their origins in nonEuropean philosophical traditions.

The historical and cultural traditions from which they write are qualitatively and in essence so different that their analysis, interpretations and conclusions are of necessity going to produce 'naive and perverse' accounts steeped in white chauvinism. ${ }^{3}$

We now turn to look at three critical areas in which Black women's experience is very different from that of white women. As we have already stated, white women have benefited fundamentally from the oppression of Black women and before any kind of collective action takes place it is necessary to reassess the basis on which we ally ourselves to the white feminist movement. The three areas we have chosen as illustrations of our thesis are the family, sexuality and the women's peace movement. Each of these areas, in very different ways point to the 'imperial' nature of feminist thought and practice.

\section{Family}

To date socialist feminist theory has sought to harness what is perceived as two strands of women's oppression - class oppression and patriarchal oppression - the one being viewed as the economic basis of relationships, the other, the social or ideological. Attempts have been made to locate patriarchal relations within the social relations of reproduction and these analyses have sought to link the modes of production and

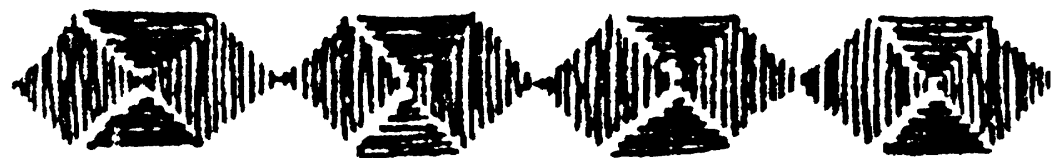


reproduction in an attempt to define women's position in a capitalist, patriarchal society. Indeed the complexities of that relationship have been discussed at length but no workable synthesis of the concepts of gender and class has emerged. Patriarchy cannot be viewed only in terms of its relationship to capital and capitalist relations but neither is it merely an analytical tool which explains the oppression of women by men within a range of different economic systems.

It is important to go back to the classic definition of patriarchy (see Barrett, 1980) which also encompassed the oppression of younger men by the father. Patriarchy is about gender oppression but it is also about power relations which are not always gender specific. The film Padre Padroni amply demonstrates this. A definition of patriarchal relations which looks only at the power of men over women without placing that in a wider political and economic framework has serious consequences for the way in which relationships within the Black community are viewed. Relationships within the Black community are structured by racism and it is a denial of racism and its relationship to patriarchy to posit patriarchal relations as if they were noncontradictory. We would argue that the arguments of radical feminists who see patriarchy as the primary determining feature of women's oppression ignores totally the inapplicability of such a concept in analysing the complex of relations obtaining in the Black communities both historically and at present (see Delphy, 1977).

The family, rightly, has been the object of much debate in the women's movement and has been cited as one of the principle sites of women's oppression - women's role in reproducing the labour force, their supposed dependence on men and the construction of a female identity through notions of domesticity and motherhood have all been challenged. Indeed within that questioning there have been attempts to elevate domestic labour to the same level of analysis as the Marxist analysis of the mode of production and the relations between capital and labour. The family and its role in the construction of a consensual ideology remains central to discussions of feminism. We would question however the ways in which white academics, particularly sociologists and anthropologists, have sought to define the role of Black women in the family.

Much work has already been done which shows the ways in which sociology, especially the sociology of 'ethnicity', pathologizes and problematizes the Black communities in Britain. Our concern here is the impact the above analyses have had on Euro-American contemporary feminist thought, particularly socialist feminists. Although it is true to say that some of these feminists have distanced themselves from the crude stereotyping common in such analyses, some stereotypes do stick and they are invariably linked to colonial and historical interpretations of the Black woman's role. The image is of the passive Asian woman subject to oppressive practices within the Asian family with an emphasis on wanting to 'help' Asian women liberate themselves from their role. Or there is the strong, dominant Afro-Caribbean woman, the head of the household who despite her 'strength' is exploited by the 'sexism' which is seen as being a strong feature in relationships between Afro-Caribbean men and women. So although the crude translation of theories of ethnicity which have become part and parcel of the nation's common sense image of Black people (see Lawrence, 1982) may not be accepted by many white feminists, they are influenced by the ideas and nowhere is this more apparent than in debates about the family, where there has certainly been a failure to challenge particular pathological ideas about the Black family. There is little

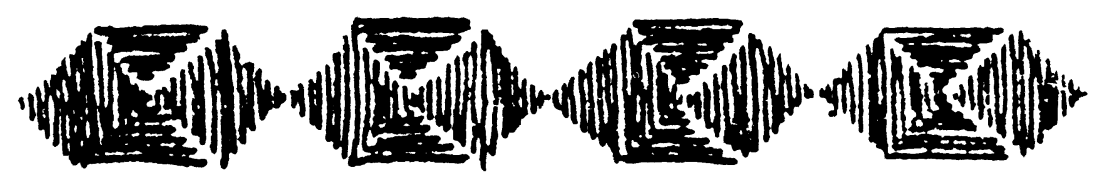


or no engagement by white feminists with the contradictions which constitute and shape our role as women in a family context, as sisters, aunts or daughters. For both Black and white women, it is a critical issue which has to be addressed, but in this area of struggle it is Black women who have sought to look critically at the family, its strengths and weaknesses, its advantages and disadvantages, its importance for certain women in class and race terms and all this in the broader context of state harassment and oppression of Black people (see Parita Trivedi and Amina Mama in this issue).

There are further considerations which shape the socialist feminist view of the Black family in Britain and these relate strongly to the politics of the British left, and their perception of colonial, neo-colonial and imperialist relations. There has been much debate in the Left about the ability of Third World countries to successfully achieve socialism without first coming fully into capitalist relations and this view has also been expressed by socialist feminists (Molyneux, 1981). Within this framework the Black family is seen as a problem in terms of its ability to adapt to advanced capitalist life - it is seen as a force prohibiting 'development' - and this view has been informed by the broader political and social analysis of our countries of origin as backward, needing to emerge into the full force of capitalist expansion before overcoming their economic, social, political and cultural 'underdevelopment'. It is important to remember that many socialist feminists come out of this Left tradition, a tradition which has been crucial in shaping their political awareness.

The relationship of Britain to her colonies has shaped not only the experience of Black people in Britain but also that of the indigenous working class. As Katznelson states, 'contemporary racial attitudes have been shaped by the colonial experience, forged in the crucible of imperialism' (1970). For the majority of people in Britain their experience of 'race' has been at the level of the ideological, despite the economic, political and cultural nature of British imperialism. Their experience has been mediated through the concept of 'benign paternalism'. In this way autonomous Black movements and their history of struggle were conveniently abstracted out of the conception of Blacks held by the majority of people in Britain. The fact that Black people were said to have no history conveniently stripped them of a whole tradition of struggle. Black people however brought the knowledge of those struggles with them from the Caribbean and these have been instrumental in shaping the nature of Black resistance in Britain.

In the Caribbean, struggles against colonialism and the advanced forms of imperialist expansion have been waged on a number of different levels. The Caribbean islands have a long history of resistance in the urban areas and also in the country on large plantations and sugar estates. Spontaneous riots erupted with amazing regularity throughout the slave and post slave period. Eric Williams catalogues a number of labour and other disputes in the late 1930's which illustrate this point:

The road to revolution has been marked out. The revolution broke out in the years 1935-1938.... A sugar strike in St Kitts, 1935; a coal strike in St Lucia, 1935; labour disputes on the sugar plantations of British Guiana, 1935; an oil strike, which became a general strike, in Trinidad, 1937 (Williams, 1970).

And the list goes on. The move from the periphery to the centre was not a process of depoliticization for Black people; rather the migration process served to focus and sharpen the nature of the struggle.

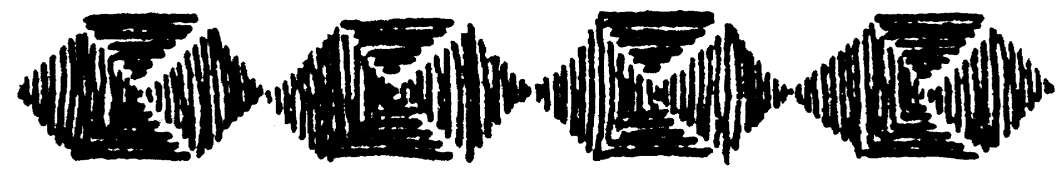


It was the same in the Asian sub-continent - a series of uprisings and struggles some of which are mentioned in Parita Trevendi's essay (this issue). On the African continent the pre-nationalist struggles tell the same story, for example, the Mau Mau campaign. This experience is certainly lacking in certain contemporary analyses of Black people in Britain.

White feminists have fallen into the trap of measuring the Black female experience against their own, labelling it as in some way lacking, then looking for ways in which it might be possible to harness the Black women's experience to their own. Comparisons are made with our countries of origin which are said to fundamentally exploit Black women. The hysteria in the western women's movement surrounding issues like arranged marriages, purdah, female headed households, is often beyond the Black woman's comprehension - being tied to so called feminist notions of what constitutes good or bad practice in our communities in Britain or the Third World.

In rejecting such analyses we would hope to locate the Black family more firmly in the historical experiences of Black people - not in the romantic idealized forms popular with some social anthropologists, and not merely as a tool of analysis. There are serious questions about who has written that history and in what form, questions which have to be addressed before we as Black people use that history as an additional element of our analysis. Black women cannot just throw away their experiences of living in certain types of household organization; they want to use that experience to transform familial relationships. Stereotypes about the Black family have been used by the state to justify particular forms of oppression. The issue of fostering and adoption of Black kids is current: Black families are seen as being 'unfit' for fostering and adoption. Racist immigration legislation has had the effect of separating family members, particularly of the Asian community, but no longer is that legislation made legitimate just by appeals to racist ideologies contained in notions of 'swamping'. Attempts have actually been made by some feminists to justify such legislative practices on the basis of protecting Asian girls from the 'horrors' of the arranged marriage system. White feminists beware - your unquestioning and racist assumptions about the Black family, your critical but uninformed approach to 'Black culture' has found root and in fact informs state practice.

\section{Sexuality}

Sexuality has been and continues to be a central issue of discussion and debate within the white women's movement, and much political energy has been spent on understanding and questioning sexuality and sexual oppression:

... feminism has thrown up enormous challenges in the whole field of sexuality. We have challenged the 'rights' of men to women's bodies; the compulsory nature of heterosexuality; the stigma and invisibility of lesbianism; the primacy of the nuclear family; rigid gender roles - patriarchal definitions of what is 'natural'; the violence of rape; the exploitation of pornography; sexist imagery and symbolism. Even the importance and priority given to sexual relationships have been questioned (Cartledge and Ryan, 1983).

While such debates rage virulently amongst white feminists, many Black women have rightly felt that we do not have the 'luxury' of engaging in them in the context of the

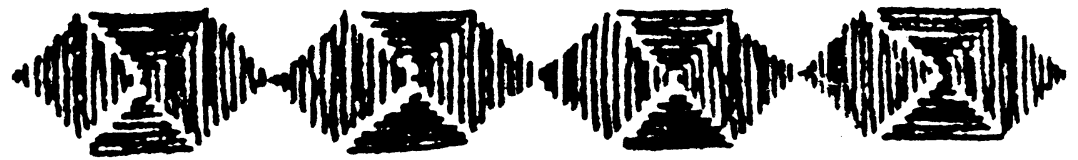


intense racism of the British state. But the fact that Black women have been peripheral to these debates that have taken place within the women's movement, does not mean that we have not always thought about and discussed these issues with each other. The ways in which we have discussed and prioritized issues around sexuality have differed markedly from white women.

Such theoretical debates, while important components in any theory and discussion of women and sexuality, have not been areas of focus for Black women's energy and action because in many ways our theoretical and political agendas have already been circumscribed and defined for us.

Our very position as Black women in a racist society has meant that we have been forced to organize around issues relating to our very survival. The struggle for independence and self determination and against imperialism has meant that for Black and Third World women in Britain and internationally, sexuality as an issue has often taken a secondary role and at times not been considered at all.

As we have increasingly grown confident in our feminism, some of us have begun to look at the area of sexuality in ways that are relevant to us as Black women. The absence of publicly overt debates on and around sexuality by Black women does not mean that such discussions have not been taking place. As illustrated in Brixton Black women's group's analysis of the demise of the Organisation of Women of Asian and African Descent (OWAAD), this was and continues to be one area which has been recognized as an essential element of Black feminist practice and theory.

It is necessary to remember that:

In many cases we have been deprived of the right to act in ways which are sexually authentic for us, in part because once again we have been defined by others. For example, white men for centuries have justified their sexual abuse of Black women by claiming that we are licentious, always 'ready' for any sexual encounter (Hull, Scott and Smith, 1982).

More specifically when challenging heterosexuality as the norm many Black lesbians have had to face the profound homophobia of both Blacks and whites. As Barbara Smith comments when talking about the American situation:

Implicit in our communities attitudes towards Black lesbians is the notion that they have transgressed both sexual and racial norms. Despite all the forces with which we must contend, Black women have a strong tradition of sexual self determination (Hull, Scott and Smith, 1982).

Black women's continued challenges to the question of forced sterilization and the use of the contraceptive drug Depo Provera has meant that such campaigns as the National Abortion Campaign have been forced to reassess the relevance of their single issue focus for the majority of working class, Black women, and to change the orientation of their campaigns and actions.

At the annual conference of the National Abortion Campaign (NAC) in October, 1983, the two major factors within NAC split into two separate campaign groups; one, continuing to work on the single issue of abortion rights and the other a reproductive rights group. The reproductive rights group rightly recognize that:

It is impossible to campaign for 'our right to choose' without demanding total reproductive freedom. They think it can be racist to try to win abortion on

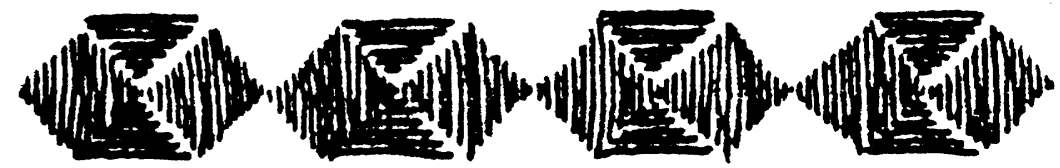


demand in isolation as that type of campaign ignores the fact that many doctors are quite willing to give abortions to Black and working class women and any women who have other characteristics they don't approve of (Spare Rib 83).

It is worthwhile at this point to look back at history and highlight the fact that some of the unquestioned assumptions inherent in contemporary feminist demands have remained the same as those of the nineteenth and early twentieth-century feminists who in the main were pro-imperialist. One strand of early feminism in Britain has its roots in the radical liberal and social purity campaign work of Josephine Butler who drew on religious rhetoric with its notions of purity and impurity, virtue and vice and linked her analysis to aspects of contemporary theories of evolution. Christabel Pankhurst, a leading light at the time, echoed her agreement with the growing eugenic lobby when she said, 'sex powers are given... as a trust to be used not for... immorality and debauchery, but... reverently and in a union based on love for the purpose of carrying on the race' (emphasis added; Bland 1983).

While the growth of the birth control movement and birth control information and clinics in the 1920s and 1930s is to be recognised as a crucial gain for women in the fight for control over their own bodies, the grounds on which such a movement gained respectability was not on a woman's right to self determination but on the grounds of eugenics and health. Marie Stopes was a committed eugenist, and the name of her organization - the Society for Constructive Birth Control and Racial Progress clearly stated her racialist position. The class interest of many such women was revealed when such woman's organizations as the National Society for Equal Citizenship and 'The Woman's Co-operative Guild' supported campaigns to legalize sterilization in the 1930s for certain groups of 'unfit' persons, i.e. working class women.

Many suffragists campaigned around slogans such as 'votes for women, chastity for men' and created new spaces for women but their compliance with the development of an ideology of women as mothers and reproducers of the race highlighted their interest in upholding white supremacy.

At the beginning of the nineteenth century a healthy and growing population was seen as a national resource and neo-Malthusians alongside eugenists recommended contraception not only as an artificial check on population but also as a means of selective limitation of population growth to prevent the 'deterioration' of the 'race' and decline as an imperial nation through the proliferation of those they regarded as 'unfit' (to breed). It must however be said that there was a small section of women who attempted to counter the Eugenicist movement, such as Stella Brown.

In 1958 Charles Kingsley argued that over-population was impossible 'in a country that has the greatest colonial empire that the world has ever seen', and he believed that it was 'a duty, one of the noblest of duties to help the increase of the English race as much as possible' (Davin, 1978). Women were being defined as the breeders of the race, bearing and rearing the next generation of soldiers and workers of the imperial race. Within this context developed a new definition of women's role and the pressures which led to the formation of an ideology of motherhood:

In many cases the terms in which reforms to do with marriage, child rearing and bearing were proposed also involved reference to the nation, the empire, or the race.... (Davin, 1978).

White feminists have attacked this for its oppressiveness to them but not on the

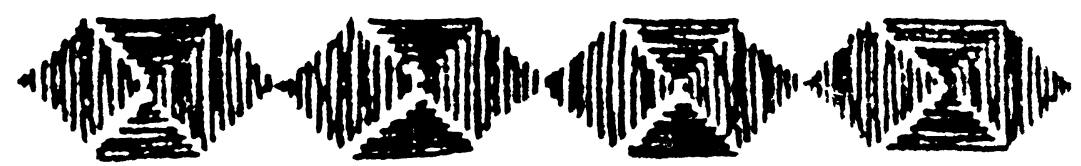


grounds of race and anti-imperialism.

Such a development of an ideology of women as mothers duty bound to reproduce for the race went alongside the development of an imagery of them as vulnerable creatures who needed protection not only at home but also in the colonies.

There are historical counterparts of contemporary white male use of the image of vulnerable and defenceless white women being raped and mugged by Black men, images which are reinforced by racist ideologies of black sexuality. Also in responding to the use of physical violence to control white women's sexuality white feminists have singularly failed to see how physical violence to control the sexuality of Black men is a feature of our history (eg lynching). This has implications for analyses and campaigning around sexual violence.

Historically, there are many instances of how white women's vulnerability to physical violence from men has been used to bring in oppressive legislation which justified an extension of police and state powers, with oppressive results for both men and women in countries under colonial rule. For instance in 1926 a White Women's Protection Ordinance was passed in Papua (New Guinea), then under British rule, which introduced the death penalty for the crime of rape or attempted rape of any European female. The 'Black Peril', or the fear that 'native men', who were seen as endowed with 'strong sex instincts' particularly for white women, were going around in their hordes raping white women, was the background to this severe legislation. In fact there was little proof that this was happening.

Not only were there double standards for white men, who, far from being penalized for having sexual relationships with local Black women, were in fact encouraged to 'satisfy' their 'natural' desires; but furthermore Black women's experiences and vulnerability to male violence was judged to be of little consequence.

Doubtless there are native women who set the highest value on their chastity, but they are the exception and the rape of an ordinary native woman does not present any element of comparison with the rape of a respectable white woman even where the offence upon the latter is committed by one of her own race and colour (Ware 1983).

The racist ideology that black and immigrant men are the chief perpetrators of violent crimes against women permeates not only the racist media fed regularly by police 'revelations' of 'racial' crime statistics as in 1982 but also sections of the white women's liberation movement as illustrated by their actions and sometimes their nonaction.

For example, the compliance of many white feminists with the racist media and the police is shown in their silence when public hysteria is periodically whipped up through images of white women as innocent victims of black rapists and muggers. When white feminists have called for safer streets, and curfew of men at nights they have not distanced themselves from the link that exists in common sense racist thinking between street crime and Black people. Again, when women marched through Black inner city areas to 'Reclaim the Night' they played into the hands of the racist media and the fascist organizations, some of whom immediately formed vigilante groups patrolling the streets 'protecting' innocent white women by beating up black men. Therefore we would agree that 'any talk of male violence that does not emphatically reject the idea that race or colour is relevant automatically reinforces these racist images'(Ware 1983).

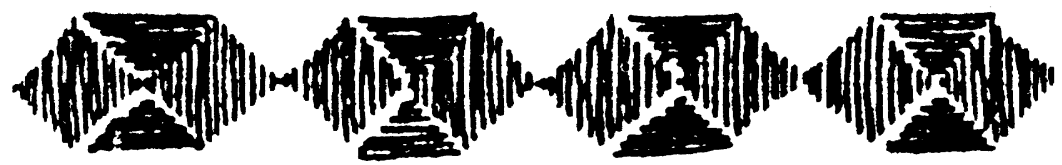


Black women's sexuality has been used in various oppressive ways throughout imperialist history. For instance, during slavery women were forced to breed a slave labour force, raped, assaulted and experimented on; practices that still continue today under 'scientific' and sophisticated guises.

For Asian women, one such historical example of control over them was in the form of the Contagious Diseases Act passed in India in 1868. Throughout the nineteenth century the British military in India was only concerned with maintaining an efficient and 'healthy' army who had 'natural' sexual desires which needed to be fulfilled. Prostitution was encouraged and local Indian women were either taken on as 'mistresses' or regularly visited in the brothels both within and outside of the cantonments. Such practices were so widespread that venereal disease increased rapidly. What the Act did was call for compulsory registration of brothels and prostitutes and periodical medical examinations and compulsory treatment of such 'diseases'. The soldiers were not required to do this. This is just one example of state regulation of prostitutes which was a result of imperialist policies which required the maintenance of huge and 'healthy' armies (Ballhatchett, 1980).

In identifying the institution of the family as a source of oppression for women, white feminists have again revealed their cultural and racial myopia, because for Asian women in particular, the British state through its immigration legislation has done all it can to destroy the Asian family by separating husbands from wives, wives from husbands and parents from children.

But while many Black feminists would agree that the ideology of mother/wife roles is oppressive to women and that marriage only serves to reinforce and institutionalize that oppression, in a political climate where the state is demanding proof of the 'genuine' nature of 'arranged marriages' as a blatant attack on Asian culture, and Asian people's right to enter this country, we demand the right to choose and struggle around the issue of family oppression ourselves, within our communities without state intervention, and without white feminists making judgements as to the oppressive nature of arranged marriages.

Many white feminists have argued that as feminists they find it very difficult to accept arranged marriages which they see as reactionary. Our argument is that it is not up to them to accept or reject arranged marriages but up to us to challenge, accept, or reform, depending on our various perspectives, on our own terms and in our own culturally specific ways.

\section{Nuclear Power on the North London Line}

With the setting up of the Greenham Common Women's Peace camp in 1981, world attention has focussed on the women's peace movement in Britain. Thousands of women have identified the threat of a nuclear war as a priority issue to organize around. While some feminists have sought to distance themselves from women peace activists who have fallen into the trap of elevating the feminine nature of women with its stress on mothering and nurturing, finding its organized manifestation in groups such as the Families against the Bomb and Babies against the Bomb, other problems remain (Radical Feminist Papers, 1984).

The women's peace movement is and continues to remain largely white and middle-class because yet again their actions and demands have excluded any under-

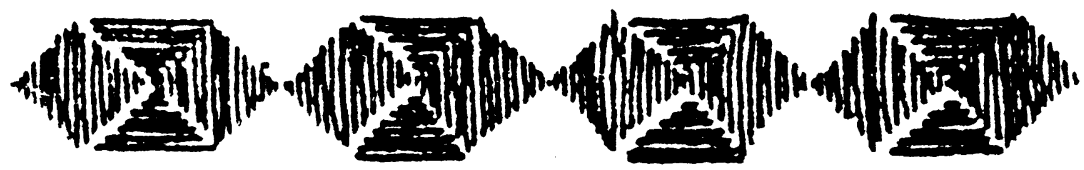


standing or sensitivity to Black and Third World women's situations.

Black women's political priorities have not been to organize around the siting of American cruise missiles at Greenham or to focus on the disarmament campaigns. This has been inevitable given the implicit and often explicit nationalist sentiments of its campaigns as much as the overall framework within which they have addressed these questions. The patriotic cries of 'We want to protect our country' which extend both to the mixed left anti-nuclear groups as much as sections of the women's peace movement is not one with which many Black people seek to or want to identify with, particularly when we know that we are not recognized or accepted as legitimate and equal inhabitants of this island and are continuously fighting for our right to be here. The parochial concerns of the Campaign for Nuclear Disarmament (CND) and the women's peace movement are manifest in their unwillingness to take up any international issues. Why, for instance, are they not exposing, campaigning and mobilizing against Britain's role in illegal mining of uranium in Namibia for fuel for its Trident submarines? Why are connections not being made with people in the Pacific who are fighting for land rights? Why is there continued silence and inaction on the war going on in Britain's own 'backyard', Northern Ireland? Why is it that some white women who have sought to involve Black women in their peace campaigns at Greenham can only include them by asking them to service them yet again and play the role of caterers?

It is inevitable that such questions and issues do not feature on the agendas of either the women's peace movement or the CND, because both these movements are imbued with the uncritical acceptance of the concept of 'the nation', in particular the 'British nation'. Their failure to distance themselves or be critical of anti-Americanism prevalent in public opinion which supports nuclear arms but opposes American nuclear arms is a result of their deepseated and entrenched patriotism. In Britain, there is not a single social or political institution that has not been fundamentally affected by the ideology of Empire and its corollary of British superiority.

As Black women we are under no illusion that the racism prevalent in the wider women's movement and in British society generally will be absent from the women's peace movement. The racism inherent in it can be illustrated by countless experiences Black women have had with white feminists who are peace activists.

The slogan 'Yanks out' and 'Yankees go home' has been widely adopted by many women peace activists and is an illustration of racism arising out of a confusion of collapsing the American state with individual Americans. An example of such a tactic is an incident witnessed recently when a group of white, middle-class women began to shout and chant 'Yanks out' and 'Yankee go home' at a Black American soldier walking through the train carriage they were sitting in. To some of the Black women present this was reminiscent of 'Blacks go home' and 'wogs out'. When confronted with the racism of their action one woman justified their actions by saying that in an individual situation, such confrontations are necessary and legitimate. Necessary and legitimate to whom?

It is precisely because the power relations evident in such an individual confrontation are complex, that a strategy of isolating out one Black soldier and chanting 'Yankee go home' is racist. The class and race power, white, middle-class women have is taken for granted and not questioned by them and the contradictions involved in such a group confronting one black soldier by shouting at him escaped most of these women. The history of lynchings of Blacks in America cannot be relegated to the pages of history books; the collective experience of such intense racism is alive in every Black individual's conscious and unconscious psyche, as is the history of white women's power over Black men (Davis, 1982).

That such a politically simplistic response came from a group of women who were 
part of a women's delegation to picket Armagh prison in solidarity with Irish women political prisoners, is surprising and is indicative of their lack of analysis and understanding of the intrinsic links between racism and imperialism.

Internationally, while Black and Third World women are fighting daily battles for survival, for food, land and water, western white women's cries of anguish for concern about preserving the standards of life for their children and preserving the planet for future generations sound hollow. Whose standards of life are they fighting to preserve? - white, middle-class standards undoubtedly. Recently, Madhu Kishwar, an Indian feminist came to speak to the Women For Life on Earth and she stressed that what is needed is a realisation that:

A movement for disarmament begins with a movement against the use of guns, the everyday weapons. Here (in Britain) you may have a fear of a nuclear holocaust and death and destruction - in India millions die of water pollution - that is a more deadly weapon for women in India. I think it is very important that nuclear piles be made targets for political action, but we have to begin with confronting the guns and the dandas (sticks) that is disarmament for us (Kishwar, 1984).

Many women at Greenham have begun to experience for the first time the brutality of the British police and some are slowly realizing why many Black women are not willing to deliberately expose themselves to it when it is an everyday occurrence for them, anyway. Black women are up against the state everyday of our lives, and the terror of a coercive police force, a highly trained military and the multifarious arms of the 'welfare' state are familiar ground to us.

The choice to demonstrate 'peacefully' or take non-direct action has never been available to us. When thousands of Black people marched against the National Front racists in Southall, in Lewisham, police were ready to do battle with their truncheons, riot shields and horses. Self defence in such instances has been the only option and the armoury available to us has consisted of bricks, dustbinlids, chilli bombs and petrol bombs. The question of deliberating over how best to fight our oppressor is not an abstract one for us nor for people involved in national liberation struggles around the world.

In saying that as Black women we have sought not to prioritize our political energies on organizing around 'peace' and disarmament, does not in any way mean we do not consider these as crucial political issues.

Indeed, the arms race is fundamentally political and the complexities of the new cold war and the increasing drive for American global supremacy are crucial questions of importance which concern us all. But, it is only when western peace activists, be they male or female, begin to broaden the parameters of their campaigns and integrate an international perspective within their frameworks, will there be a radical shift away from the predominantly white composition of these movements.

\section{Conclusion}

For us the way forward lies in defining a feminism which is significantly different to the dominant trends in the women's liberation movement. We have sought to define the boundaries of our sisterhood with white feminists and in so doing have been critical not only of their theories but also of their practice. True feminist theory and practice entails an understanding of imperialism and a critical engagement with challenging racism - elements which the current women's movement significantly lacks, but which are intrinsic to Black feminism. We are creating our own forms and content. As Black women we have to look at our history and at our experiences at the hands of a 
racist British state. We have to look at the crucial question of how we organize in order that we address ourselves to the totality of our oppression. For us there is no choice. We cannot simply prioritize one aspect of our oppression to the exclusion of others, as the realities of our day to day lives make it imperative for us to consider the simultaneous nature of our oppression and exploitation. Only a synthesis of class, race, gender and sexuality can lead us forward, as these form the matrix of Black women's lives.

Black feminism as a distinct body of theory and practice is in the process of development and debate both here in Britain and internationally and has begun to make significant contribution to other movements of liberation, as well as challenging the oppression and exploitation of Black women.

\section{Notes}

1 Some attempts have been made to look at both racism and feminism. For example Jenny Bourne in her essay (1983) 'Towards an anti-racist feminism' attempts to locate anti racist practice within a (white) feminist context. However Jenny Bourne's essay fails adequately to address contemporary debates within feminism and ignores the contribution of black feminists to the broader debate around issues of racism, feminism, class and sexuality.

2 There have been a range of debates around socialism and feminism which have ignored the issue of race. See for example Rowbotham, Segal and Wainwright (1979), and Sargent (1981) which has only one essay on 'The Incompatible Menage a Trois.

3 See Cedric Robinson (1983) for a comprehensive analysis of the Black radical tradition.

\section{References}

ANZADUA, G and MARAGA, L (1981), editors, This Bridge Called my Back, Writings by Radical Women of Colour New York: Persephone Press

BALLHATCHETT, Kenneth (1980) Race, Sex and Class Under the Raj: Imperial Attitudes and Policies 1793-1905, London: Wiedenfeld and Nicholson.

BARRETT, Michèle (1980) Women's Oppression Today, Problems in Marxist Feminist Analysis London: Verso

BLAND, Lucy (1983) 'Purity, Motherhood, Pleasure or Threat' in Cartledge and Ryan (1983).

BOURNE, Jenny (1983) 'Towards an Anti-Racist Feminism' Race and Class Vol 25 Summer 1983 no. 1, pp 1-22.

BUJRA, J, and CAPLAN, P (1978) editors, Women United, Women Divided, Cross Cultural Perspectives on Female Solidarity London: Tavistock.

CARBY, Hazel (1982) 'White Woman Listen! Black Feminism and the Boundaries of Sisterhood' in Centre for Contemporary Cultural Studies (1982).

CARTLEDGE, Sue and RYAN, Joanna (1983) Sex and Love, New Thoughts on Old Contradictions London: Women's Press.

CENTRE FOR CONTEMPORARY CULTURAL STUDIES (1982) (Race and Politics Group) The Empire Strikes Back, Race and Racism in 70's Britain London: Hutchinson.

DAVIN, Anna (1978) 'Imperialism and Motherhood' History Workshop Journal, Issue 5, Spring 1978.

DAVIS, Angela (1982) Women, Race and Class London: Women's Press.

DELPHY, Christine (1977) The Main Enemy: a Materialist Analysis of Women's Oppression London: Women's Research and Resources Centre Publications.

EISENSTEIN, Zillah (1979) editor, Capitalist Patriarchy and the Case for Socialist Feminism New York: Monthly Review Press.

HOOKS, Bell (1982) Ain't I a Woman? Black Women and Feminism London: Pluto. 
HULL, Gloria T, SCOTT, Patricia Bell, and SMITH, Barbara (1982) editors, All the Women are White, All the Blacks are Men, but Some of Us are Brave New York: Feminist Press.

JOSEPH, Gloria and LEWIS, Jill (1981) Common Differences: Conflicts in Black and White Perspectives London: Anchor.

KATZNELSON, Ira (1973) Black Men, White Cities London, Oxford University Press.

KISHWAR, Madhu (1984) Interview in Outwrite no 22, February 1984.

LEWIS, Gail and PARMAR, Pratibha (1983) 'Review Essay of American Black Feminist Literature' Race and Class vol 25 Autumn 1983.

MARABELLE, Manning (1983) How Capitalism Underdeveloped Black America New York: Southend Press.

MOLYNEUX, Maxine (1981) 'Socialist Societies Old and New: Progress Towards Women's Emancipation' Feminist Review no 8, pp 1-34.

RADICAL FEMINIST PAPERS (1984) Breaching the Peace, Collection of Radical Feminist Papers London: Onlywomen Press.

ROBINSON, Cedric J (1983) Black Marxism: the Making of the Black Radical Tradition London: Zed Press.

ROWBOTHAM, Sheila, SEGAL, Lynne, and WAINWRIGHT, Hilary (1979) Beyond the Fragments: Feminism and the Making of Socialism London: Merlin.

SARGENT, Lydia (1981) editor, The Unhappy Marriage of Marxism and Feminism London: Pluto.

SPARE RIB (1983) 'Report of the National Abortion Campaign Conference' Spare Rib November 1983.

SIVANANDAN, A (1982) 'Capitalism, Highest Stage of Imperialism. Warren and the Third World' Race and Class no. 241982.

WARE, Veronica (1983) 'Imperialism, Racism and Violence against Women' Emergency no 1, winter 83/4.

WARREN, Bill (1980) Imperialism, Pioneer of Capitalism London: New Left Books.

WILlIAMS, Eric (1970) From Columbus to Castro, History of the Caribbean 1492-1969 London: André Deutch.

\section{Further Reading}

BEECHEY, Veronica (1979) 'On Patriarchy' Feminist Review no 3.

BROWN, Wilmette (1983) Black Women and the Peace Movement London: International Women's Day Convention.

CENTRE FOR CONTEMPORARY CULTURAL STUDIES (1978), Women's Studies Group, Women Take Issue London: Hutchinson.

DAVIS, Miranda (1983) editor, Third World, Second Sex, Women's Struggles and National Liberation London: Zed Press.

JORDAN, June (1981) Civil Wars New York: Beacon.

KUHN, Annette and WOLPE, Ann Marie (1978) editors, Feminism and Materialism London: Routledge and Kegan Paul.

McROBBIE, Angela, and McCABE, Trisha (1982), editors Feminism for Girls: an Adventure Story London: Routledge and Kegan Paul.

RICH, Adrienne (1980) On Lies, Secrets and Silence London: Virago.

REITER, R. (1975) editor, Towards an Antbropology of Women New York: Monthly Review Press.

RUBIN, Gayle (1975) 'The Traffic in Women: Notes on the Political Economy of Sex' in Reiter (1975).

SMITH, Barbara (1983) Home Girls New York: Kitchen Table Press.

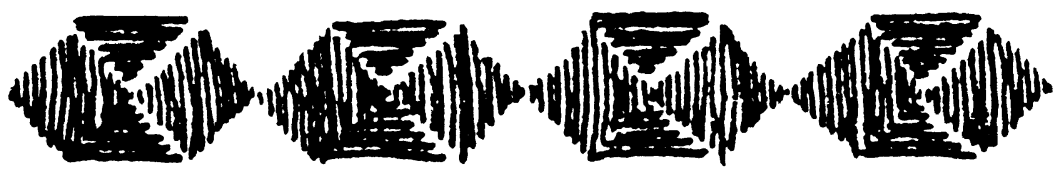

